\section{SOI: 1.1/TAS DOI: 10.15863/TAS International Scientific Journal Theoretical \& Applied Science}

p-ISSN: 2308-4944 (print)

e-ISSN: 2409-0085 (online)

Year: 2017

Issue: 01

Volume: 45

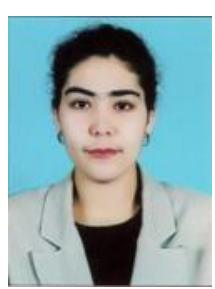

Intizor Atabaevna Matkarimova teacher at Urgench branch of TUIT, Independent researcher of department "Statistics",

Tashkent state university of Economics, Uzbekistan.

Phone: + 99890-578-19-51

Published: $30.01 .2017 \quad$ http://T-Science.org

SECTION 31. Economic research, finance, innovation, risk management.

\title{
MAJOR CHANGES IN THE SYSTEM OF NATIONAL ACCOUNTS 2008 AND THEIR IMPACT ON MACROECONOMIC INDICATORS
}

Abstract: In this Paper were studied the Main Problems of Transition of National Accounting Systems of the Republic of Uzbekistan to System of International Standards of National Accounting Systems, as well as defined the main directions of calculations of its indicators, and considered the main objectives of its formation.

Key words: National Accounting Systems, NAS-1993, NAS-2008, Transitional Consumption, Gross Added Value, Gross Domestic Product.

Language: English

Citation: Matkarimova IA (2017) MAJOR CHANGES IN THE SYSTEM OF NATIONAL ACCOUNTS 2008 AND THEIR IMPACT ON MACROECONOMIC INDICATORS. ISJ Theoretical \& Applied Science, 01 (45): 116-119.

Soi: http://s-o-i.org/1.1/TAS-01-45-22 Doi: crossef https://dx.doi.org/10.15863/TAS.2017.01.45.22

\section{Introduction}

System of National Accounts (SNA) is a system of interconnected indicators used for the description and analysis of macroeconomic processes. It is used in a majority of countries with market economies. SNA is originated in the most developed countries in connection with the need for the information needed to make decisions on regulation of the market economy, the formation of economic policy.

The need for a system of macroeconomic indicators was recognized even by the English economist William Petty, who has carried out the world's first people who estimate of national income of the country. The first macroeconomic model of the national economy created by Frenchman Francois Kene, the head of the school of the Physiocrats. Currently, the transformed to SNA is objectively necessary for the analysis of macroeconomic indicators and to ensure comparability in international studies.

The first recognized standard as international was the SNA 1953. Later, it was updated in 1968, 1993 and 2008.

Relevance. Changes have taken a place in connection with the globalization of the world economy, ecological processes, social conditions in the world led to the need for the system of national accounts improvement, to better statistical monitoring of the complex processes that occur in the world community economies.
The new version of updated SNA is a process which requires more time. Because it involved professional statisticians and scientists from all over the world. Changes made for the SNA 2008 is based on a careful study of the processes that occur during the rise of the economies of the world community, processes such as the globalization of the economy, environmental and social problems. In order to maintain international comparability it is necessary to consider the possibility of their accomplishment in all countries without taking into account the level of development and geographical location of country.

Research objective. Describe the main changes in the system of national accounts and their impact on the formation of the macroeconomics.

SNA 2008 are created for enhancing the coverage and improve the quality of estimates of GDP and its growth rate.

The costs of research and development and weapons are most significant sides of the process. Since in connection with these changes significantly altered the calculations the volume and structure of GDP.

The issue of research activities include research and development, produced by orders from the outside and in-house, both market and non-market producers.

According to the principles of the SNA 1993 research and development being undertaken to increase efficiency or productivity, or to obtain other 
benefits in the future, and research and development were seen as part of intermediate consumption. At one time not to consider them as supporting activities is recommended, and whenever it is possible to allocate a separate institution as a secondary activity.

Since SNA 1993 use of the issue of research activities is recognized as an intermediate consumption, there has been an underestimation of GDP. Accordingly, despite the fact that the results of research activities (the supply of knowledge) is the essential foundation for the economic growth in the future, they are not considered as gross fixed capital as assets in the balance sheet of assets and liabilities, and therefore net worth of the country in result underestimated.

In the SNA 2008 under research and development costs are understood to creative work undertaken on a systematic basis to rise the knowledge stock, including knowledge of man, culture and society, and the use of this stock of knowledge to evolve new possibilities of its application. It is not intended to include human capital in the assets in the SNA. Cost of research and development ( $R$ \& D) should be defined in terms of the economic benefits that can be expected to obtain in the future. This includes the provision of public services in the case of $\mathrm{R} \& \mathrm{D}$ acquired government. In fact, $\mathrm{R} \& \mathrm{D}$, which do not provide an economic benefit of their owner, are not subject to fixed assets in the SNA 2008. and should be considered as intermediate consumption. If the market value of the research is not directly observed, it is in accordance with the agreement can be estimated by the sum of incurred costs, including the cost of unsuccessful $\mathrm{R}$ \& D (1).

At the same time in the SNA 2008 explained that the research activities that brings economic benefits to the owner, must be regarded as intermediate consumption (1).

In the SNA 2008 changing approach to the use of the reflection of the results of research activities. Costs are recorded as gross fixed capital formation, as the results of scientific research can be used repeatedly. In the balance sheet assets and liabilities are allocated to a separate item ("R \& D") as part of fixed assets. This will result in an increase in the absolute value of GDP and its growth rate, provided outstripping growth of spending on research and development.

With the inclusion of expenditure on R \& D in gross patents are no longer seen as an asset in the SNA 2008 .. Instead, the agreement on the patent must be regarded as a legal agreement concerning the terms and conditions under which access to R \& D. The patent agreement is a kind of license to use, which is recognized as the basis for payment for services, or for the acquisition of an asset (1).

The main problem as in many countries of the world and in our country is to relate the scope of work for Research in gross fixed capital formation and intermediate consumption. It all comes down to what is currently difficult to determine whether it is possible to obtain economic benefits from scientific research in the future.

With regard to military expenditure in the SNA 1993, offensive weapons and their means of delivery is not included in the accumulation of capital, regardless of their service life, and the costs are recorded as intermediate consumption in the accounts of the general government sector.

Weapons systems include vehicles and other equipment, such as military aircraft, tanks, radars and launch system, and so on.. Most single-use weapons use, such as ammunition, missiles, rockets, bombs and so on. E., Is reflected in the accounts as the material circulating assets for military purposes. However, some disposable objects with high destructive capability may be used to inhibit aggression for a long period of time and therefore meet the general criteria for classification as a core (1).

For gross fixed capital formation also includes the construction of military airports, runways, fortifications, military bases and ports. The construction of these facilities is carried out on a contractual basis non-financial corporations, but after payment of the contract sum, they should be referred to the gross fixed capital formation by general government.

Inventories military facilities consist of a single use, such as ammunition, missiles, rockets, bombs and so on. E., Delivered by weapons or weapons systems, (1).

It is necessary to separate the costs of weapons, which in terms of the SNA 2008 are capital in nature, from the costs that are not related to fixed assets and must be taken into account in the SNA as current expenses.

In the SNA 2008 introduced changes in the definition of the cost of transfer of ownership. All costs associated with the acquisition and disposal of assets are referred to costs associated with the transfer of ownership. Costs associated with the transfer of property rights consist of the following items:

a. All professional or commissions fees, the costs of which are as a unit, the acquired assets and units, realizing assets; These include legal fees, architects, surveyors, engineers, and commissions real estate agents and auctioneers;

b. any trade and transport costs, specified separately in the invoice presented to the buyer;

c. all taxes payable by the unit acquiring the asset in connection with the transfer of ownership of the asset;

d. any tax payable in connection with the disposal of an asset; 
e. any costs related to the delivery, installation or removal are not included in the price of the asset acquired or disposed of; and

f. any final expenses incurred at the end of life of the asset, for example, required to ensure the safety of the construction or restoration of the environment where the asset was located, (1).

All of these costs of ownership transfer in the SNA 2008 are reflected in the accounts as gross fixed capital formation. They belong to the buyer or seller of an asset, depending on which unit bears the costs. Costs charged to consumption of fixed capital over the period during which the new owner is supposed to be the holder of the asset, except for the final costs to be written off over the life of the asset.

In the SNA 2008 identified three broad groups of services provided by the central bank. These are services related to the implementation of monetary policy, financial intermediation services and other "border" services that can be attributed to one or the other group mentioned above. Services related to the implementation of monetary policy, are by nature collective services to the community as a whole, and so are non-market output. Financial intermediation services are by their nature of individual services and generally to be regarded as a market. Borderline cases, such as the services of supervision and control, can be considered as market or non-market, depending on whether there is sufficient service fee to compensate for the cost of production services (1).

In the SNA 2008 attempts to clarify the impact of the various functions of the central banks of maintenance, evaluation and use of their release. To this end, the central bank should be allocated places that produce market and nonmarket services, if the difference is significant for the accounts as a whole. Based on the current cost applies to non-market services. Their use is recorded as acquisition of collective services by the general government, that is, intermediate consumption, production and final consumption expenditure by general government, which will lead to an increase in GDP. To finance this acquisition in the secondary distribution of income should be shown the conditional transfer from the bank (financial corporations sector) government sector. Market services are valued at market prices, and may be provided to all sectors of the economy, but their customers are mainly commercial banks.

In cases where the market can not be separated from the non-market release, the entire issue of the central bank should be treated as non-market and assessed by the sum of production costs (1).

The business of financial corporations worldwide in the last twenty years has undergone significant structural changes: the value of the usual financial intermediation decreased and increased the role of the portfolio management of financial assets for the purpose of receiving holding gains. To better reflect the growing importance of these services in the SNA 2008 a lot of attention paid to the definition of financial corporations; in return for financial services expressly included margin on transactions with foreign currency and securities.

If non-financial corporations providing financial services for a fee, this is not regarded as FISIM. However, the units lend their funds will be considered financial corporations providing financial services for a fee if they provide loans to a number of clients and take the financial risk in case of bankruptcy of the debtor.

The SNA 2008 introduces several more detailed classification of the financial corporations sector, to provide greater flexibility and better alignment with other systems of monetary and financial statistics, such as the system of the International Monetary Fund and European Central Bank. The financial corporation sector is divided into 9 sub-sectors (SNA 1993, there were five) in accordance with the activities of units in the market and the liquidity of their liabilities.

These sub-sectors include:

1. the central bank;

2. The corporation receiving deposits, except for the central bank;

3. money market funds (FDR);

4. The investment fund is not a money market;

5. Other financial intermediaries, except insurance corporations and pension funds;

6. Auxiliary financial corporation;

7. captive financial institutions and moneylenders;

8. Insurance Corporation (SC);

9. pension funds $(\mathrm{PF})$.

The issue of insurance services in the SNA 1993 is calculated as the difference between insurance premiums and claims (on an accrual basis). Therefore, the release can vary greatly, and even be negative as a result of major disasters, and these fluctuations impact on GDP and balance of payments (in the part of reinsurance).

The informal sector accounts for a significant part of the production in many countries, including the CIS countries. SNA - 2008, new developments and statistical sources that enable to use more specific approaches to the definition of the scope of the informal sector. In particular, the materials of the Delhi Group on Informal Sector Statistics and the Guide to the measurement of non-observed economy, prepared by the OECD, ILO, UNECE, IMF, the CIS Statistical Committee.

New features of the SNA 2008 will increase the analytical value of a number of important indicators of the SNA. However, in practice it will require solving a number of problems related to obtaining background information and the lack of methodological tools. 


\begin{tabular}{|c|c|c|c|c|c|c|}
\hline Impact Factor: & $\begin{array}{l}\text { ISRA (India) } \\
\text { ISI (Dubai, UAE } \\
\text { GIF (Australia) } \\
\text { JIF }\end{array}$ & $\begin{array}{l}=1.344 \\
=0.829 \\
=0.564 \\
=1.500\end{array}$ & $\begin{array}{l}\text { SIS (USA) } \\
\text { PИНЦ (Russia } \\
\text { ESJI (KZ) } \\
\text { SJIF (Morocco }\end{array}$ & $\begin{array}{r}=\mathbf{0 . 9 1 2} \\
=\mathbf{0 . 2 3 4} \\
=\mathbf{1 . 0 4 2} \\
=\mathbf{2 . 0 3 1}\end{array}$ & $\begin{array}{l}\text { ICV (Poland) } \\
\text { PIF (India) } \\
\text { IBI (India) }\end{array}$ & $\begin{array}{l}=6.630 \\
=1.940 \\
=4.260\end{array}$ \\
\hline
\end{tabular}

One of the important methodological and informational problems in the work of statisticians many countries is the issue of coverage of all economic activities within the production boundary of the SNA, which is closely linked with the assessment of "non-observed economy", including:

- illegal activities;

- shadow (underground, black, shadow) of the enterprise;
- informal activities of households.

\section{Conclusion}

In conclusion, we can say that SNS performs an essential function which provides an information basis for making decisions in the formulation of macroeconomic policy both in individual countries and in general in the world community.

\section{References:}

1. (2012) System of National Accounts, 2008. The European Commission, the UN, IMF, OECD, World Bank, New York.

2. Ivanov YN, et al. (1996) System of National Accounts - a tool of macroeconomic analysis. Tutorial. Edited by N. Ivanova.- M: Finstatinform.

3. Ryabushkin BT (2002) National accounts and economic balansy.- M: FIS.

4. Salin VN, Kudryashov S (2006) System of National Accounts. - M .: FiS.

5. (2002) Decree of President of Republic of Uzbekistan about "Reorganization of ministry of Macroeconomics and statistics of Republic of Uzbekistan”, “Khalq suzi” newspaper. 2002, 26 December.

6. Gaibnazarov BK (2001) To design statistics which are in conformity with world standards.// "Economic herald of Uzbekistan" № 3, 2001, $16 \mathrm{p}$.

7. Mahmudov BM (2003) SYSTEM OF NATIONAL ACCOUNTS. T.: Academy.

8. Qoraboev AR (2009) Systems of national accounts.-T.: "Economics-Finance".

9. Mahmudov BM (2011) SYSTEM OF NATIONAL ACCOUNTS. T.: TSUE, 2011

10. (2017) sayt Gosudarstvenniy komitet po statistike.Available:www.stat.uz (Accessed: 10.01.2017). 